\title{
EXAMINATION OF ATTITUDES OF SPECIAL EDUCATION TEACHERS TOWARDS CHILD NEGLECT AND ABUSE REPORTING IN TERMS OF DIFFERENT VARIABLES
}

\author{
Fatima Şenda Değirmenci ${ }^{1}$, \\ Cahit Nuri², \\ Cemaliye Direktör ${ }^{3 i}$ \\ ${ }^{1}$ Cyprus International University, \\ Faculty of Education, \\ Department of Special Education, \\ North Cyprus \\ ${ }^{2}$ Asst. Prof. Dr., \\ Cyprus International University, \\ Faculty of Education, \\ Department of Special Education, \\ North Cyprus \\ ${ }^{3}$ Asst. Prof. Dr., \\ European University of Lefke, \\ Faculty of Art and Science, \\ Department of Psychology, \\ North Cyprus
}

\begin{abstract}
:
In this study, the attitudes of special education teachers working in various schools in the Turkish Republic of Northern Cyprus towards reporting child neglect and abuse were examined according to various variables. In accordance with this purpose, 86 special education teachers participated in the study. A personal information form and a "teacher attitudes towards the reporting of child abuse and neglect" survey were applied to the participants. Four out of ten of the participating teachers indicated that they received education on child abuse, and nine out of ten stated that marrying a child younger than 18 should be considered as an abuse. On the other side, one in six teachers stated that they had been abused as children. In the matter of responding to reports of child abuse and neglect and meeting the need, teachers do not find the current system effective and adequate. When the responses of the teachers to the survey were examined, it was observed that they thought it was significant for teachers to fulfill their obligation of notification to reduce and prevent child abuse and neglect in the long run. As a result, it is important for teachers to have knowledge of the legal legislation on abuse of children, what civil and public institutions they can reach on this issue and what common activities
\end{abstract}

i Correspondence: email degirmencisenda@gmail.com, cnuri@ciu.edu.tr, cdirektor@eul.edu.tr 
can be carried out with them, what reactions they can give in times of crisis or critical situations, and how they can guide people. In-service training on the related issues can be shown as a requirement.

Keywords: child, child abuse, child neglect, individual with special needs, teacher

\section{Introduction}

The future of our society depends on the decent education of children and their healthy development in terms of physical, spiritual, moral, and intellectual aspects. It is the apparent truth that to reintegrate children into society in a healthy and sound manner, the need for the protection of their physical and mental health and the best education is required (Kocaer, 2006).

Children receive their primary education from their parents and then from their teachers. There is not any training given by parents and teachers to children regarding their fundamental rights and freedoms. Children grow up unconscious because they do not know their basic rights and freedoms. Children who do not know their rights are subjected to many unknown neglect and abuse. The fact that legal punishments such as child neglect and abuse are not deterrent, and the society is not made aware of this issue may lead to child neglect and abuse (Sagir, 2013). The individual's exposure to trauma, neglect and abuse during childhood and adulthood causes different problems for the individual (Albayrak, Bakoglu, Bostanc1, \& Coban, 2006).

Child abuse is a serious medical, legal, developmental, and psycho-social problem with complex causes and tragic consequences. The World Health Organization defines behaviors that are committed by an adult, either intentionally or unintentionally, that negatively affect a child's health, physical and psycho-social development, as child abuse. Sexual abuse is the use of a child who has not completed his psycho-social development and is under his age by an adult for sexual satisfaction (Kara, Bicer and Gokalp, 2004).

Child neglect and abuse is the sum of the actions or inaction of the child's parents, caregivers, or the adults around them that will negatively affect the development of the child and cause serious harm to the child (Bahar, Savas \& Bahar, 2009). Child neglect and abuse are classified differently. Particularly childhood abuse occurs as physical, sexual, and emotional abuse (Siyez, 2003). In addition to cases of child abuse, the type of case that a child is exposed to that affects their life is cases of neglect. Neglect is classified as follows: physical neglect, sexual neglect, and emotional neglect (Yargic, Ersoy, \& BatmazOflaz, 2012). Actions ranging from rape, incest, child pornography, exhibitionism, speeches that provoke sexuality, watching pornographic films, stroking genitals, and oral sex are included in the spectrum of sexual abuse (Trrasc1 \& Goren, 2007).

Preventive effects of healthcare professionals and teachers are ignored in terms of prevention and early detection of child abuse and neglect. It cannot be ignored that the school, which is one of the places where the child spends the most time, has the most important influence and quality in observing behavioral changes and variations, defining 
child neglect, abuse, and risk potential, preventing and reporting. Teachers should have the highest level of knowledge on abuse and neglect to be able to perform the necessary actions and functional aspects in terms of child neglect and abuse (Dilsiz \& Magden, 2015). In addition, school term is essential for individuals with special needs, as in children with normal development. Getting used to their teachers, the love of teachers and trusting their teachers connect children with special needs more to school. Teachers should know their students well. Teachers who know their students can prevent their students from being neglected and abused or notice if they have experienced neglect and abuse.

At the stage of detecting cases of neglect and abuse, the people with whom the children encounter the most outside the family can play an effective role, namely teachers. Teachers can notice observable changes in children and play a role in legally handling the issue with their attitudes in cases of neglect and abuse. Dereobalı, Cirak, Karadag and Sonmez (2013) determined in their study that most of the preschool teachers encountered children who were subjected to violence and emphasized that teachers can make a significant contribution to the prevention of abuse, neglect, and violence. Akgül (2015), in his study, which examined the sexual abuse reporting of preschool education staff, found that teachers' attitudes towards reporting were positive, but they did not make any reports, including in suspicious cases, and they had a lack of information about the obligation to report. Yet, one of the teacher's duties is to be able to recognize the abuse risk factor faced by the child and to report it to the respective departments. Equivalently, another occupational group under responsibility is healthcare workers. Therefore, in this study, it was aimed to evaluate the knowledge and behavior of family physicians and teachers towards recognizing and evaluating child neglect and abuse cases.

It is understood that the issue of child neglect and abuse is an important problem within the framework of today's state understanding. Child rights violations and child abuse are considered crucial in the TRNC. Extensive work needs to be done to prevent these abusive actions. It is fundamental to address the problem and cases of child neglect and abuse not only in individuals with normal development but also in individuals with special needs. Children who are more disadvantaged than children with normal development should necessarily receive special education. It should never be ignored that these children are at the top of the risk groups in terms of the risk of neglect and abuse. Children with special needs are thought to be more exposed to child neglect and abuse than children with normal development. Hence, it is expected that teachers working in the special education field will contribute to the reporting of child neglect and abuse, and the issue of child neglect and abuse should be studied in special education settings. The main problem of this particular study is "examining the attitudes of special education teachers towards reporting child neglect and abuse according to different variables".

Within the framework of this main problem, answers to the following subproblems were sought: 
1) What is the attitude of special education teachers towards reporting child abuse and neglect?

2) Do the attitudes of special education teachers towards reporting child abuse and neglect differ by gender?

3) Do the attitudes of special education teachers towards reporting child abuse and neglect differ according to their marital status?

4) Do the attitudes of special education teachers towards reporting child abuse and neglect differ according to their status of receiving education on child abuse and neglect?

5) Do the attitudes of special education teachers towards reporting child abuse and neglect differ according to whether they have been abused at some point in their life?

\section{Methods}

In this section, an account of information was given under the titles of research model, study group, data collection tool, validity and reliability, data collection process and data analysis.

\subsection{Research Model}

The quantitative method in collecting data in this study has been a descriptive research conducted for special education teachers to report child abuse and neglect, and the model of the research is the survey model. "Screening models are research approaches that aim to describe a past or present situation as it exists. In this model, it is tried to define the event, individual or object subject to the research in its own conditions and as it is" (Karasar, 2012).

\subsection{Population and Sample}

Special education teachers residing in the Turkish Republic of Northern Cyprus and working in private and public institutions in the fall term of 2019-2020 constitute the research population. Eighty-six special education teachers interviewed using the easily accessible sampling method from the particular research population constitute the research sample. Table 1 demonstrates the socio-demographic frequencies of the teachers as numbers and percentages.

Table 1: Introductory Characteristics of Teachers

\begin{tabular}{|l|c|c|}
\hline Variable & Number (N=86) & Percentage (\%) \\
\hline Gender & 59 & 66,28 \\
\hline Woman & 29 & 33,72 \\
\hline Man & 26 & 30,23 \\
\hline Professional Seniority & 32 & 37,21 \\
\hline 1-5 years & 28 & 32,56 \\
\hline 6-15 years & \multicolumn{2}{|l|}{} \\
\hline 16 years and above
\end{tabular}


CHILD NEGLECT AND ABUSE REPORTING IN TERMS OF DIFFERENT VARIABLES

\begin{tabular}{|l|c|c|}
\hline Whether or not to Receive Education on Abuse & \multicolumn{1}{|l|}{} \\
\hline Educated & 37 & 43,02 \\
\hline Non - educated & 49 & 56,98 \\
\hline Whether or not to be Abused in Their Own Lives & 13 & 15,12 \\
\hline Yes & 73 & 84,88 \\
\hline No & 86 & 100 \\
\hline Total &
\end{tabular}

The socio-demographic characteristics of the teachers covered by the research are given in Table 1. According to the data obtained from the table, $66.28 \%$ of the teachers in the research are women and $33.72 \%$ are men. Considering the distribution of professional seniority of the participants in the research, it was observed that $30.23 \%$ had professional seniority of $1-5$ years, $37.21 \% 6-15$ years and $32.56 \% 16$ years and above. While $43.02 \%$ of the teachers within the scope of the study were educated on abuse, 56.98\% did not. It was indicated that $15.12 \%$ of the participants were abused in their lives, and $84.88 \%$ were not abused.

\subsection{Data Collection Tools}

A questionnaire form consisting of two parts, namely "Teacher Attitudes Survey Towards Reporting of Child Abuse and Neglect" and introductory features, was used in the collection of research data.

\subsubsection{Introductory Features}

It was aimed to indicate the demographic characteristics of the teachers included in the study, such as gender, professional seniority, and to determine their views on prior education on child abuse and neglect, and on being abused.

\subsubsection{Teacher Attitudes Survey Towards the Reporting of Child Abuse and Neglect}

In order to determine the attitudes of teachers who constitute the research population Towards Reporting of Child Abuse and Neglect, the Teacher Attitudes Survey Towards the Reporting of Child Abuse and Neglect, which was created by Yetis and Ziyalar (2018), was used. There are 15 items in the Teacher Attitudes Survey Towards the Reporting of Child Abuse and Neglect. Since there is no structural validity-reliability study for these 15 questions, they are not evaluated as a scale, and each item is evaluated individually.

\subsection{Collection of Data}

Participation in the study was grounded on volunteerism. A form was filled in for ethical approval from the university, and the necessary permissions were obtained by applying for the "Teacher Attitudes Survey Towards the Reporting of Child Abuse and Neglect" according to the Ministry of Education and Culture. The study was carried out throughout the TRNC. Institutions in all districts in the TRNC were included in the study. Data were distributed to institutions for special education teachers who volunteered to participate in the study. Data were obtained from 86 returned questionnaires. 


\subsection{Statistical Analysis of Data}

Data collected from special education teachers by questionnaire method were transferred to computer environment and for statistical analysis, Statistical Package for Social Sciences (SPSS) 24.0 data analysis software was used. The distribution of special education teachers included in the study according to their socio-demographic characteristics was determined via frequency analysis and demonstrated by distribution tables. Frequency analysis was also used in the distribution of teachers' responses to the Teacher Attitudes Survey Towards the Reporting of Child Abuse and Neglect, and the distribution of responses to each item was shown. The square test was used to compare the responses of the teachers included in the study to the Teacher Attitudes Survey Towards the Reporting of Child Abuse and Neglect according to their socio-demographic characteristics. Because of the small sample size, the "I do not agree" and "I am indecisive" responses of the teachers to the Teacher Attitudes Survey Towards the Reporting of Child Abuse and Neglect were combined.

\section{Finding and Comments}

In this section, in addition to the demographic findings of the participants, the findings related to the sub-goals of the research are given under headings.

Table 2: Teachers' Responses to the Teacher Attitudes Survey

Towards the Reporting of Child Abuse and Neglect

\begin{tabular}{|l|c|c|c|c|c|c|}
\hline \multirow{2}{*}{ Items } & \multicolumn{2}{|c|}{$\begin{array}{c}\text { I do not } \\
\text { agree }\end{array}$} & \multicolumn{2}{|c|}{ Neutral } & \multicolumn{2}{|c|}{$\begin{array}{c}\text { I } \\
\text { Agree }\end{array}$} \\
\cline { 2 - 7 } & $\mathbf{N}$ & $\%$ & $\mathbf{N}$ & $\%$ & $\mathbf{N}$ & $\%$ \\
\hline $\begin{array}{l}\text { 1. If I am in doubt about child abuse or neglect, I will report } \\
\text { it. }\end{array}$ & 2 & 2,33 & 2 & 2,33 & 82 & 95,35 \\
\hline $\begin{array}{l}\text { 2. I believe that I have full professional competence in } \\
\text { understanding and interpreting the symptoms of child abuse } \\
\text { or neglect. }\end{array}$ & 7 & 8,14 & 21 & 24,42 & 58 & 67,44 \\
\hline $\begin{array}{l}\text { 3. A mandatory reporting process is necessary for children to } \\
\text { live a safe and healthy life. }\end{array}$ & 2 & 2,33 & 6 & 6,98 & 78 & 90,70 \\
\hline $\begin{array}{l}\text { 4. Although my colleagues and managers at the institution I } \\
\text { work for do not agree with me, I report situations that I find } \\
\text { suspicious. }\end{array}$ & 2 & 2,33 & 5 & 5,81 & 79 & 91,86 \\
\hline $\begin{array}{l}\text { 5. In order to reduce and prevent child abuse and neglect in } \\
\text { the long run, I think it is important for teachers to fulfill their } \\
\text { reporting obligation }\end{array}$ & 3 & 3,49 & 0 & 0,00 & 83 & 96,51 \\
\hline $\begin{array}{l}\text { 6. I find the current system effective and sufficient in } \\
\text { responding to reports of child abuse and neglect and } \\
\text { meeting the need. }\end{array}$ & 47 & 54,65 & 21 & 24,42 & 18 & 20,93 \\
\hline $\begin{array}{l}\text { 7. Especially for teachers, I think it is necessary to have a } \\
\text { regulation that defines the reporting process of child abuse } \\
\text { and neglect and clearly states the actions that need to be } \\
\text { taken. }\end{array}$ & 8 & 9,30 & 5 & 5,81 & 73 & 84,88 \\
\hline
\end{tabular}




\begin{tabular}{|l|l|l|l|l|l|l|}
\hline $\begin{array}{l}\text { 8. I believe that reporting for suspicious situations will cause } \\
\text { teachers to experience difficulties both inside and outside the } \\
\text { school. }\end{array}$ & 27 & 31,40 & 14 & 16,28 & 45 & 52,33 \\
\hline $\begin{array}{l}\text { 9. Even if I report child abuse and neglect, I think I will not } \\
\text { be able to get enough evidence or witnesses to prove the } \\
\text { truth of the incident. }\end{array}$ & 23 & 26,74 & 23 & 26,74 & 40 & 46,51 \\
\hline $\begin{array}{l}\text { 10. Reporting child abuse and neglect helps authorities reach } \\
\text { children and families and resolve the problem. }\end{array}$ & 9 & 10,47 & 10 & 11,63 & 67 & 77,91 \\
\hline $\begin{array}{l}\text { 11. In the post-reporting process, I am concerned that the } \\
\text { family or community may display angry and aggressive } \\
\text { attitudes towards the notifier }\end{array}$ & 23 & 26,74 & 15 & 17,44 & 48 & 55,81 \\
\hline $\begin{array}{l}\text { 12. After reporting of child abuse and neglect, I abstain from } \\
\text { being involved in the process, as I am concerned that the } \\
\text { child's family and society will find out who reported the } \\
\text { incident }\end{array}$ & 44 & 51,16 & 20 & 23,26 & 22 & 25,58 \\
\hline $\begin{array}{l}\text { 13. After the reporting process, I think that the competent } \\
\text { authorities will intervene quickly and effectively with the } \\
\text { child and family. }\end{array}$ & 23 & 26,74 & 18 & 20,93 & 45 & 52,33 \\
\hline $\begin{array}{l}\text { 14. I do not think reports about child abuse and neglect are } \\
\text { taken into account effectively. }\end{array}$ & 29 & 33,72 & 18 & 20,93 & 39 & 45,35 \\
\hline $\begin{array}{l}\text { 15. I believe that my undergraduate education has provided } \\
\text { me with sufficient knowledge and skills in understanding } \\
\text { and evaluating children's behavior and emotions and } \\
\text { communicating with children }\end{array}$ & 11 & 12,79 & 7 & 8,14 & 68 & 79,07 \\
\hline
\end{tabular}

According to Table 2, "1. If I am in doubt about child abuse or neglect, I will report it." 2.33\% of the participants gave I do not agree, $2.33 \%$ of them gave neutral and $95.35 \%$ of them gave I agree responses to this proposition. When it comes to the "2. I believe that I have full professional competence in understanding and interpreting the symptoms of child abuse or neglect." proposition, $8.14 \%$ of teachers gave I do not agree, $24.42 \%$ gave neutral, $67.44 \%$ gave agree responses; $2.33 \%$ did not agree with the "3. A mandatory reporting process is necessary for children to live a safe and healthy life." statement, 6.98\% were neutral, and $90.70 \%$ agreed with it. $2.33 \%$ of teachers who are the subjects of the research disagreed with the following proposal while $5.81 \%$ were neutral, and $91.86 \%$ agreed: "4. Although my colleagues and managers at the institution I work for do not agree with me, I report situations that I find suspicious." To the "5. In order to reduce and prevent child abuse and neglect in the long run, I think it is important for teachers to fulfill their reporting obligation." statement, $3.49 \%$ of participants responded with I do not agree while $96.51 \%$ of them responded with I agree.

The responses of the teachers within the study to the "6. I find the current system effective and sufficient in responding to reports of child abuse and neglect and meeting the need." statement are $54.65 \%$ disagree, $24.42 \%$ neutral and $20.93 \%$ agree. $9.30 \%$ of the teachers answered as I do not agree with the "7. Especially for teachers, I think it is necessary to have a regulation that defines the reporting process of child abuse and neglect and clearly states the actions that need to be taken." proposition whereas $5.81 \%$ of them answered as neutral and $84.88 \%$ as I agree. The answer given by the teachers to the " 8 . I believe that reporting for 
suspicious situations will cause teachers to experience difficulties both inside and outside the school." proposition was 31.40\% disagree, 16.28\% neutral and 52.23\% agree.

$26.74 \%$ of the teachers did not agree with the "9. Even if I report child abuse and neglect, I think I will not be able to get enough evidence or witnesses to prove the truth of the incident." statement since $26.74 \%$ were neutral and $46.51 \%$ agreed. $10.47 \%$ of the teachers stated that they do not agree with the statement of "10. Reporting child abuse and neglect helps authorities reach children and families and resolve the problem." while $11.63 \%$ of them answered as neutral and $77.91 \%$ of them as I agree. The answer given by the teachers of the research to the "11. In the post-reporting process, I am concerned that the family or community may display angry and aggressive attitudes towards the notifier." statement is $26.74 \%$ disagree, $17.44 \%$ neutral and $55.81 \%$ agree. On the other hand, their response to the "12. After reporting of child abuse and neglect, I abstain from being involved in the process, as I am concerned that the child's family and society will find out who reported the incident." proposition is that $51.16 \%$ I do not agree, $23.26 \%$ neutral, and $25.58 \%$ I agree.

For the "13. After the reporting process, I think that the competent authorities will intervene quickly and effectively with the child and family." statement, $26.74 \%$ of the participants stated that they do not agree, 20.93\% were neutral and $52.33 \%$ of them agreed. The responses given to the "14. I do not think reports about child abuse and neglect are taken into account effectively." proposition are 33.72\% disagree, 20.93\% neutral, 45.35\% agree. $12.79 \%$ of the teachers responded with the "15. I believe that my undergraduate education has provided me with sufficient knowledge and skills in understanding and evaluating children's behavior and emotions and communicating with children." statement as disagree, $8.14 \%$ as neutral and $79.07 \%$ answered as I agree.

Table 3: Comparison of Teachers' Responses to the Teacher Attitudes

Survey Towards the Reporting of Child Abuse and Neglect by Gender

\begin{tabular}{|c|c|c|c|c|c|c|c|}
\hline \multirow[b]{2}{*}{ Items } & & \multicolumn{2}{|c|}{ Woman } & \multicolumn{2}{|c|}{ Man } & \multirow{2}{*}{$\chi^{2}$} & \multirow{2}{*}{ p } \\
\hline & & $\mathbf{n}$ & $\%$ & $\mathrm{n}$ & $\%$ & & \\
\hline \multirow{2}{*}{$\begin{array}{l}\text { 1. If I am in doubt about child abuse } \\
\text { or neglect, I will report it. }\end{array}$} & Disagree/Neutral & 2 & 3,51 & 2 & 6,90 & & \multirow{2}{*}{0,481} \\
\hline & Agree & 55 & 96,49 & 27 & 93,10 & & \\
\hline \multirow{2}{*}{$\begin{array}{l}\text { 2. I believe that I have full } \\
\text { professional competence in } \\
\text { understanding and interpreting the } \\
\text { symptoms of child abuse or neglect. }\end{array}$} & Disagree/Neutral & 21 & 36,84 & 7 & 24,14 & \multirow{2}{*}{1,413} & \multirow{2}{*}{0,235} \\
\hline & Agree & 36 & 63,16 & 22 & 75,86 & & \\
\hline \multirow{2}{*}{$\begin{array}{l}\text { 3. A mandatory reporting process is } \\
\text { necessary for children to live a safe } \\
\text { and healthy life. }\end{array}$} & Disagree/Neutral & 7 & 12,28 & 1 & 3,45 & \multirow{2}{*}{ - } & \multirow{2}{*}{0,182} \\
\hline & Agree & 50 & 87,72 & 28 & 96,55 & & \\
\hline \multirow{2}{*}{$\begin{array}{l}\text { 4. Although my colleagues and } \\
\text { managers at the institution I work for } \\
\text { do not agree with me, I report } \\
\text { situations that I find suspicious. }\end{array}$} & Disagree/Neutral & 5 & 8,77 & 2 & 6,90 & \multirow{2}{*}{ - } & \multirow{2}{*}{0,764} \\
\hline & Agree & 52 & 91,23 & 27 & 93,10 & & \\
\hline \multirow{2}{*}{$\begin{array}{l}\text { 5. In order to reduce and prevent } \\
\text { child abuse and neglect in the long } \\
\text { run, I think it is important for teachers } \\
\text { to fulfill their reporting obligation. }\end{array}$} & Disagree/Neutral & 3 & 5,26 & 0 & 0,00 & \multirow{2}{*}{ - } & \multirow{2}{*}{0,209} \\
\hline & Agree & 54 & 94,74 & 29 & 100,00 & & \\
\hline
\end{tabular}


Fatima Şenda Değirmenci, Cahit Nuri, Cemaliye Direktör

EXAMINATION OF ATTITUDES OF SPECIAL EDUCATION TEACHERS TOWARDS

CHILD NEGLECT AND ABUSE REPORTING IN TERMS OF DIFFERENT VARIABLES

\begin{tabular}{|c|c|c|c|c|c|c|c|}
\hline \multirow{2}{*}{$\begin{array}{l}\text { 6. I find the current system effective } \\
\text { and sufficient in responding to } \\
\text { reports of child abuse and neglect and } \\
\text { meeting the need. }\end{array}$} & Disagree/Neutral & 41 & 71,93 & 27 & 93,10 & \multirow{2}{*}{-} & \multirow{2}{*}{$0,022^{*}$} \\
\hline & Agree & 16 & 28,07 & 2 & 6,90 & & \\
\hline \multirow{2}{*}{$\begin{array}{l}\text { 7. Especially for teachers, I think it is } \\
\text { necessary to have a regulation that } \\
\text { defines the reporting process of child } \\
\text { abuse and neglect and clearly states } \\
\text { the actions that need to be taken. }\end{array}$} & Disagree/Neutral & 6 & 10,53 & 7 & 24,14 & \multirow[b]{2}{*}{2,775} & \multirow[b]{2}{*}{0,096} \\
\hline & Agree & 51 & 89,47 & 22 & 75,86 & & \\
\hline \multirow{2}{*}{$\begin{array}{l}\text { 8. I believe that reporting for } \\
\text { suspicious situations will cause } \\
\text { teachers to experience difficulties both } \\
\text { inside and outside the school. }\end{array}$} & Disagree/Neutral & 27 & 47,37 & 14 & 48,28 & \multirow[b]{2}{*}{0,006} & \multirow[b]{2}{*}{0,937} \\
\hline & Agree & 30 & 52,63 & 15 & 51,72 & & \\
\hline \multirow{2}{*}{$\begin{array}{l}\text { 9. Even if I report child abuse and } \\
\text { neglect, I think I will not be able to get } \\
\text { enough evidence or witnesses to } \\
\text { prove the truth of the incident. }\end{array}$} & Disagree/Neutral & 29 & 50,88 & 17 & 58,62 & \multirow{2}{*}{0,463} & \multirow{2}{*}{0,496} \\
\hline & Agree & 28 & 49,12 & 12 & 41,38 & & \\
\hline \multirow{2}{*}{$\begin{array}{l}\text { 10. Reporting child abuse and neglect } \\
\text { helps authorities reach children and } \\
\text { families and resolve the problem. }\end{array}$} & Disagree/Neutral & 15 & 26,32 & 4 & 13,79 & \multirow{2}{*}{1,751} & \multirow{2}{*}{0,186} \\
\hline & Agree & 42 & 73,68 & 25 & 86,21 & & \\
\hline \multirow{2}{*}{$\begin{array}{l}\text { 11. In the post-reporting process, I am } \\
\text { concerned that the family or } \\
\text { community may display angry and } \\
\text { aggressive attitudes towards the } \\
\text { notifier }\end{array}$} & Disagree/Neutral & 25 & 43,86 & 13 & 44,83 & \multirow{2}{*}{0,007} & \multirow{2}{*}{0,932} \\
\hline & Agree & 32 & 56,14 & 16 & 55,17 & & \\
\hline \multirow{2}{*}{$\begin{array}{l}\text { 12. After reporting of child abuse and } \\
\text { neglect, I abstain from being involved } \\
\text { in the process, as I am concerned that } \\
\text { the child's family and society will find } \\
\text { out who reported the incident }\end{array}$} & Disagree/Neutral & 44 & 77,19 & 20 & 68,97 & \multirow[b]{2}{*}{0,683} & \multirow[b]{2}{*}{0,408} \\
\hline & Agree & 13 & 22,81 & 9 & 31,03 & & \\
\hline \multirow{2}{*}{$\begin{array}{l}\text { 13. After the reporting process, I think } \\
\text { that the competent authorities will } \\
\text { intervene quickly and effectively with } \\
\text { the child and family }\end{array}$} & Disagree/Neutral & 29 & 50,88 & 12 & 41,38 & \multirow{2}{*}{0,695} & \multirow{2}{*}{0,404} \\
\hline & Agree & 28 & 49,12 & 17 & 58,62 & & \\
\hline \multirow{2}{*}{$\begin{array}{l}\text { 14. I do not think reports about child } \\
\text { abuse and neglect are taken into } \\
\text { account effectively. }\end{array}$} & Disagree/Neutral & 28 & 49,12 & 19 & 65,52 & \multirow{2}{*}{2,084} & \multirow{2}{*}{0,149} \\
\hline & Agree & 29 & 50,88 & 10 & 34,48 & & \\
\hline \multirow{2}{*}{$\begin{array}{l}\text { 15. I believe that my undergraduate } \\
\text { education has provided me with } \\
\text { sufficient knowledge and skills in } \\
\text { understanding and evaluating } \\
\text { children's behavior and emotions and } \\
\text { communicating with children }\end{array}$} & Disagree/Neutral & 13 & 22,81 & 5 & 17,24 & \multirow{2}{*}{0,360} & \multirow{2}{*}{0,549} \\
\hline & Agree & 44 & 77,19 & 24 & 82,76 & & \\
\hline
\end{tabular}

${ }^{*} \mathrm{p}<0.05$-Fisher's Exact Test was used.

According to Table 3, 96.49\% of female teachers and $93.10 \%$ of male teachers responded as I agree with the statement "1. If I am in doubt about child abuse or neglect, I will report it.", and no statistically significant difference was found between their answers according to the gender of the teachers. $(p>0,05)$ Among the participants, female teachers who 
answered I agree with the "2. I believe that I have full professional competence in understanding and interpreting the symptoms of child abuse or neglect." statement were at a rate of $36.84 \%$ and male teachers were at a rate of $75.86 \%$. It was also observed that the difference between the responses of the teachers to this statement according to their gender was not significant ( $p>0.05$ ). 87.72\% of the female teachers stated that they agreed with the statement "3. A mandatory reporting process is necessary for children to live a safe and healthy life." whereas this rate was $96.55 \%$ at male teachers. There was no statistically significant difference between the answers they gave according to their gender $(p>0.05)$. From the participants, $91.23 \%$ of the female teachers and $93.10 \%$ of the male teachers gave the answer that they agree with the "4. Although my colleagues and managers at the institution I work for do not agree with me, I report situations that I find suspicious." statement, and no significant difference was found between their answers according to their gender ( $\mathrm{p}>$ 0.05). $94.74 \%$ of the women and all of the men indicated that they agreed with the "5. In order to reduce and prevent child abuse and neglect in the long run, I think it is important for teachers to fulfill their reporting obligation." statement, and it was determined that the difference between the responses of the teachers for this statement according to their gender was not significant $(\mathrm{p}>0.05)$.

While $28.07 \%$ of the female teachers in the study stated that they agreed with the "6. I find the current system effective and sufficient in responding to reports of child abuse and neglect and meeting the need." statement, this ratio was $6.90 \%$ when it comes to the men teachers. It was determined that the distinction between the responses of the participants for this statement according to their gender was statistically significant $(p<0.05) .89 .47 \%$ of female teachers and $75.86 \%$ of male teachers answered "I agree with the statement 7. Especially for teachers, I think it is necessary to have a regulation that defines the reporting process of child abuse and neglect and clearly states the actions that need to be taken." and no significant difference was found between the answers they gave according to their gender ( $p>0.05)$. $52.63 \%$ of female teachers and $51.72 \%$ of male teachers who answered I agree with the " 8 . I believe that reporting for suspicious situations will cause teachers to experience difficulties both inside and outside the school." statement were found to have no significant difference in terms of gender among their responses to this statement ( $p>0.05$ ). 49.12\% of the female teachers and $41.38 \%$ of the male teachers gave the answer "I agree" to the "9. Even if I report child abuse and neglect, I think I will not be able to get enough evidence or witnesses to prove the truth of the incident." statement, and it was determined that the difference between the answers given by their gender was not statistically significant ( $\mathrm{p}>0.05)$. Among the participants, $73.68 \%$ of the women and $86.21 \%$ of the men answered as "I agree with the statement 10. Reporting child abuse and neglect helps authorities reach children and families and resolve the problem." For this statement, no statistically significant difference was found between the answers given by the teachers according to their gender ( $p>0.05)$. Responses to the "11. In the post-reporting process, I am concerned that the family or community may display angry and aggressive attitudes towards the notifier." statement were $56.14 \%$ agree on female teachers and $55.17 \%$ agree on male teachers. Also, no statistically significant difference was found between the answers according to the age group ( $p>0.05)$. While 
$22.81 \%$ of female teachers agreed with the "12. After reporting of child abuse and neglect, I abstain from being involved in the process, as I am concerned that the child's family and society will find out who reported the incident." statement, this ratio was $31.03 \%$ at male teachers. Besides, it was determined that there was no statistically significant difference according to gender among their answers ( $p>0.05) .49 .12 \%$ of the female teachers participating in the study and $58.62 \%$ of the male teachers stated that they agree with the "13. After the reporting process, I think that the competent authorities will intervene quickly and effectively with the child and family." statement, and there was no statistically significant difference between the answers given by the teachers according to their gender ( $p>0.05)$. Responses for the "14. I do not think reports about child abuse and neglect are taken into account effectively." statement are $50.88 \%$ for female teachers and $34.48 \%$ for male teachers. For this statement, there was no statistically significant difference according to gender between the answers given by the teachers ( $\mathrm{p}>0.05$ ). While $77.19 \%$ of the female teachers answered I agree with the statement "15. I believe that my undergraduate education has provided me with sufficient knowledge and skills in understanding and evaluating children's behavior and emotions and communicating with children." this ratio was $82.76 \%$ at male teachers. There was no statistically significant difference between the answers given by the teachers according to their gender $(\mathrm{p}>0.05)$.

Table 4: Comparison of Teachers' Responses to the Teacher Attitudes Survey Towards the Reporting of Child Abuse and Neglect by Professional Seniority

\begin{tabular}{|c|c|c|c|c|c|c|c|}
\hline & & \multicolumn{2}{|c|}{$\begin{array}{l}15 \text { years } \\
\text { and below }\end{array}$} & \multicolumn{2}{|c|}{$\begin{array}{l}16 \text { years } \\
\text { and above }\end{array}$} & \multirow[t]{2}{*}{$\chi^{2}$} & \multirow[t]{2}{*}{ p } \\
\hline & & $\mathbf{n}$ & $\%$ & $\mathrm{n}$ & $\%$ & & \\
\hline \multirow{2}{*}{$\begin{array}{l}\text { 1. If I am in doubt about child abuse } \\
\text { or neglect, I will report it. }\end{array}$} & Disagree/Neutral & 2 & 5,41 & 2 & 4,08 & \multirow[b]{2}{*}{ - } & \multirow{2}{*}{0,773} \\
\hline & Agree & 35 & 94,59 & 47 & 95,92 & & \\
\hline \multirow{2}{*}{$\begin{array}{l}\text { 2. I believe that I have full } \\
\text { professional competence in } \\
\text { understanding and interpreting the } \\
\text { symptoms of child abuse or neglect. }\end{array}$} & Disagree/Neutral & 13 & 35,14 & 15 & 30,61 & \multirow{2}{*}{0,196} & \multirow{2}{*}{0,658} \\
\hline & Agree & 24 & 64,86 & 34 & 69,39 & & \\
\hline \multirow{2}{*}{$\begin{array}{l}\text { 3. A mandatory reporting process is } \\
\text { necessary for children to live a safe } \\
\text { and healthy life. }\end{array}$} & Disagree/Neutral & 4 & 10,81 & 4 & 8,16 & \multirow{2}{*}{ - } & \multirow{2}{*}{0,676} \\
\hline & Agree & 33 & 89,19 & 45 & 91,84 & & \\
\hline \multirow{2}{*}{$\begin{array}{l}\text { 4. Although my colleagues and } \\
\text { managers at the institution I work for } \\
\text { do not agree with me, I report } \\
\text { situations that I find suspicious. }\end{array}$} & Disagree/Neutral & 5 & 13,51 & 2 & 4,08 & & \multirow{2}{*}{0,113} \\
\hline & Agree & 32 & 86,49 & 47 & 95,92 & & \\
\hline \multirow{2}{*}{$\begin{array}{l}\text { 5. In order to reduce and prevent } \\
\text { child abuse and neglect in the long } \\
\text { run, I think it is important for } \\
\text { teachers to fulfill their reporting } \\
\text { obligation. }\end{array}$} & Disagree/Neutral & 3 & 8,11 & 0 & 0,00 & & \multirow{2}{*}{$0,042^{*}$} \\
\hline & Agree & 34 & 91,89 & 49 & 100,00 & & \\
\hline \multirow{2}{*}{$\begin{array}{l}\text { 6. I find the current system effective } \\
\text { and sufficient in responding to } \\
\text { reports of child abuse and neglect and } \\
\text { meeting the need. }\end{array}$} & Disagree/Neutral & 24 & 64,86 & 44 & 89,80 & \multirow{2}{*}{7,918} & \multirow{2}{*}{$0,005^{*}$} \\
\hline & Agree & 13 & 35,14 & 5 & 10,20 & & \\
\hline
\end{tabular}


Fatima Şenda Değirmenci, Cahit Nuri, Cemaliye Direktör

EXAMINATION OF ATTITUDES OF SPECIAL EDUCATION TEACHERS TOWARDS

CHILD NEGLECT AND ABUSE REPORTING IN TERMS OF DIFFERENT VARIABLES

\begin{tabular}{|c|c|c|c|c|c|c|c|}
\hline \multirow{2}{*}{$\begin{array}{l}\text { 7. Especially for teachers, I think it is } \\
\text { necessary to have a regulation that } \\
\text { defines the reporting process of child } \\
\text { abuse and neglect and clearly states } \\
\text { the actions that need to be taken. }\end{array}$} & Disagree/Neutral & 7 & 18,92 & 6 & 12,24 & \multirow[b]{2}{*}{0,732} & \multirow[b]{2}{*}{0,392} \\
\hline & Agree & 30 & 81,08 & 43 & 87,76 & & \\
\hline \multirow{2}{*}{$\begin{array}{l}\text { 8. I believe that reporting for } \\
\text { suspicious situations will cause } \\
\text { teachers to experience difficulties } \\
\text { both inside and outside the school. }\end{array}$} & Disagree/Neutral & 14 & 37,84 & 27 & 55,10 & \multirow{2}{*}{2,519} & \multirow{2}{*}{0,112} \\
\hline & Agree & 23 & 62,16 & 22 & 44,90 & & \\
\hline \multirow{2}{*}{$\begin{array}{l}\text { 9. Even if I report child abuse and } \\
\text { neglect, I think I will not be able to } \\
\text { get enough evidence or witnesses to } \\
\text { prove the truth of the incident. }\end{array}$} & Disagree/Neutral & 20 & 54,05 & 26 & 53,06 & \multirow{2}{*}{0,008} & \multirow{2}{*}{0,927} \\
\hline & Agree & 17 & 45,95 & 23 & 46,94 & & \\
\hline \multirow{2}{*}{$\begin{array}{l}\text { 10. Reporting child abuse and neglect } \\
\text { helps authorities reach children and } \\
\text { families and resolve the problem. }\end{array}$} & Disagree/Neutral & 12 & 32,43 & 7 & 14,29 & \multirow[b]{2}{*}{4,033} & \multirow[b]{2}{*}{$0,045^{*}$} \\
\hline & Agree & 25 & 67,57 & 42 & 85,71 & & \\
\hline \multirow{2}{*}{$\begin{array}{l}\text { 11. In the post-reporting process, I am } \\
\text { concerned that the family or } \\
\text { community may display angry and } \\
\text { aggressive attitudes towards the } \\
\text { notifier. }\end{array}$} & Disagree/Neutral & 12 & 32,43 & 26 & 53,06 & \multirow[b]{2}{*}{3,638} & \multirow{2}{*}{0,056} \\
\hline & Agree & 25 & 67,57 & 23 & 46,94 & & \\
\hline \multirow{2}{*}{$\begin{array}{l}\text { 12. After reporting of child abuse and } \\
\text { neglect, I abstain from being involved } \\
\text { in the process, as I am concerned that } \\
\text { the child's family and society will find } \\
\text { out who reported the incident. }\end{array}$} & Disagree/Neutral & 30 & 81,08 & 34 & 69,39 & \multirow{2}{*}{1,514} & \multirow{2}{*}{0,219} \\
\hline & Agree & 7 & 18,92 & 15 & 30,61 & & \\
\hline \multirow{2}{*}{$\begin{array}{l}\text { 13. After the reporting process, I think } \\
\text { that the competent authorities will } \\
\text { intervene quickly and effectively with } \\
\text { the child and family. }\end{array}$} & Disagree/Neutral & 19 & 51,35 & 22 & 44,90 & \multirow[b]{2}{*}{0,352} & \multirow[b]{2}{*}{0,553} \\
\hline & Agree & 18 & 48,65 & 27 & 55,10 & & \\
\hline \multirow{2}{*}{$\begin{array}{l}\text { 14. I do not think reports about child } \\
\text { abuse and neglect are taken into } \\
\text { account effectively. }\end{array}$} & Disagree/Neutral & 19 & 51,35 & 28 & 57,14 & \multirow{2}{*}{0,285} & \multirow{2}{*}{0,593} \\
\hline & & 18 & 48,65 & 21 & 42,86 & & \\
\hline \multirow{2}{*}{$\begin{array}{l}\text { 15. I believe that my undergraduate } \\
\text { education has provided me with } \\
\text { sufficient knowledge and skills in } \\
\text { understanding and evaluating } \\
\text { children's behavior and emotions and } \\
\text { communicating with children. }\end{array}$} & Disagree/Neutral & 11 & 29,73 & 7 & 14,29 & \multirow{2}{*}{3,038} & \multirow{2}{*}{0,081} \\
\hline & Agree & 26 & 70,27 & 42 & 85,71 & & \\
\hline
\end{tabular}

${ }^{*} \mathrm{p}<0.05$-Fisher's Exact Test was used.

Among the teachers within the scope of the study, $94.59 \%$ of the teachers whose professional seniority was 15 years or less, and $95.92 \%$ of the teachers who had 16 years or more professional seniority agreed with the "1. If I am in doubt about child abuse or neglect, I will report it." statement. There was no statistically significant difference between the responses they gave according to their professional seniority ( $p>0.05)$. When it comes to the "2. I believe that I have full professional competence in understanding and interpreting the symptoms of child abuse or neglect." statement, $64.86 \%$ of teachers with 15 years or less professional seniority and $69.39 \%$ of teachers with 16 years or more agreed with it. There 
was also no significant difference between the responses of teachers to this statement according to their professional seniority $(\mathrm{p}>0.05)$. Those who answered I agree with the "3. A mandatory reporting process is necessary for children to live a safe and healthy life." statement were $89.19 \%$ for teachers with 15 years or less professional seniority, and $91.84 \%$ for teachers with professional seniority of 16 years or more and there was no statistically significant difference between their responses according to their professional seniority ( $p>0,05) .86 .49 \%$ of those with 15 years or less professional seniority and $95.92 \%$ of those with 16 years or more professional seniority stated that they agreed with "4. Although my colleagues and managers at the institution I work for do not agree with me, I report situations that I find suspicious." statement, and there was no significant difference between their responses to this statement according to their professional seniority $(\mathrm{p}>0,05)$. Among the participants, those who responded "I agree with the 5. In order to reduce and prevent child abuse and neglect in the long run, I think it is important for teachers to fulfill their reporting obligation." statement was $91.89 \%$ in those with 15 years or less professional seniority, and $100 \%$ in those with 16 years or more professional seniority. For this proposition, a statistically significant difference was found between the answers given by the teachers according to their professional seniority $(p<0,05) .35 .14 \%$ of teachers with 15 years or less professional seniority and $10.20 \%$ of those with 16 years and more agreed with the "6. I find the current system effective and sufficient in responding to reports of child abuse and neglect and meeting the need." statement and it was determined that there was a statistically significant difference between the answers they gave according to their professional seniority $(\mathrm{p}<0,05)$.

$81.08 \%$ of teachers with a professional seniority of 15 years or less and $87.76 \%$ of teachers with 16 years and more agreed with the statement "7. Especially for teachers, I think it is necessary to have a regulation that defines the reporting process of child abuse and neglect and clearly states the actions that need to be taken." and there was no statistically significant difference between their answers according to their professional seniority $(\mathrm{p}>0,05)$. Among the teachers who agreed with the "8. I believe that reporting for suspicious situations will cause teachers to experience difficulties both inside and outside the school." statement, $62.16 \%$ had 15 years or less professional seniority and $44.90 \%$ had 16 years or more professional seniority. There was also no statistically significant difference between their responses according to their professional seniority $(p>0,05) .45 .95 \%$ of the participants whose professional seniority was 15 years or less and $46.94 \%$ of the participants who had 16 years and more agreed with the statement "9. Even if I report child abuse and neglect, I think I will not be able to get enough evidence or witnesses to prove the truth of the incident." and there was no significant difference between the answers they gave according to their professional seniority $(p>0,05)$. According to the professional seniority of the teachers, $67.57 \%$ of those with a seniority of 15 years or less, and $85.71 \%$ of those with a seniority of 16 years or more, agreed with the "10. Reporting child abuse and neglect helps authorities reach children and families and resolve the problem." It was determined that there is a statistically significant difference between the responses of teachers according to their professional seniority $(p<0,05)$. The responses to the " 11 . In the 
post-reporting process, I am concerned that the family or community may display angry and aggressive attitudes towards the notifier." statement are $67.57 \%$ of teachers with a seniority of 15 years or less, and $46.94 \%$ of teachers with seniority of 16 years or more. For this statement, it has been determined that there is no significant difference between the answers given by the teachers according to their professional seniority $(p>0,05)$. In consideration of the responses of the teachers to the "12. After reporting of child abuse and neglect, I abstain from being involved in the process, as I am concerned that the child's family and society will find out who reported the incident." statement, $81.08 \%$ of those with 15 years or less professional seniority and $69.39 \%$ of those with 16 years or more professional seniority answered, "I don't agree/ I'm undecided". It has been observed that there is no statistically significant difference between the responses according to professional seniority $(\mathrm{p}>0,05)$.

According to professional seniority, the teachers who give the answer that I agree with the "13. After the reporting process, I think that the competent authorities will intervene quickly and effectively with the child and family." statement are $48.65 \%$ for those with 15 years or less seniority, and $55.10 \%$ for those with seniority of 16 years or more. Moreover, there was no significant difference among the responses according to professional seniority $(\mathrm{p}>0,05)$. For the "14. I do not think reports about child abuse and neglect are taken into account effectively." statement, $48.65 \%$ of teachers with a professional seniority of 15 years and below and $42.86 \%$ of teachers with a professional seniority of 16 years or more give the answer "I agree". When the answers were examined, it was determined that there was no statistically significant difference between their answers according to their professional seniority $(\mathrm{p}>0,05)$. Those who answered I agree with the "15. I believe that my undergraduate education has provided me with sufficient knowledge and skills in understanding and evaluating children's behavior and emotions and communicating with children." statement are 70.27\% of teachers with 15 years or less professional seniority, and $85.71 \%$ of teachers with 16 years or more professional seniority. The difference between the responses of the participants to this statement according to their professional seniority was not found to be statistically significant $(\mathrm{p}>0,05)$.

Table 5: Comparison of Teachers' Responses to the Teacher Attitudes

Survey Towards the Reporting of Child Abuse and Neglect According to their Educational Status on Child Abuse and Neglect $(\mathrm{n}=86)$

\begin{tabular}{|c|c|c|c|c|c|c|c|}
\hline & & \multicolumn{2}{|c|}{ Educated } & \multicolumn{2}{|c|}{ Non-Educated } & \multirow{2}{*}{$\chi^{2}$} & \multirow{2}{*}{$\mathrm{p}$} \\
\hline & & $\mathbf{n}$ & $\%$ & $\mathbf{n}$ & $\%$ & & \\
\hline \multirow{2}{*}{$\begin{array}{l}\text { 1. If I am in doubt about child } \\
\text { abuse or neglect, I will report } \\
\text { it. }\end{array}$} & Disagree/Neutral & 1 & 2,70 & 3 & 6,12 & \multirow{2}{*}{-} & \multirow{2}{*}{0,456} \\
\hline & Agree & 36 & 97,30 & 46 & 93,88 & & \\
\hline \multirow{2}{*}{$\begin{array}{l}\text { 2. I believe that I have full } \\
\text { professional competence in } \\
\text { understanding and } \\
\text { interpreting the symptoms of } \\
\text { child abuse or neglect. }\end{array}$} & Disagree/Neutral & 9 & 24,32 & 19 & 38,78 & \multirow{2}{*}{2,005} & \multirow{2}{*}{0,157} \\
\hline & Agree & 28 & 75,68 & 30 & 61,22 & & \\
\hline
\end{tabular}


Fatima Şenda Değirmenci, Cahit Nuri, Cemaliye Direktör

EXAMINATION OF ATTITUDES OF SPECIAL EDUCATION TEACHERS TOWARDS

CHILD NEGLECT AND ABUSE REPORTING IN TERMS OF DIFFERENT VARIABLES

\begin{tabular}{|c|c|c|c|c|c|c|c|}
\hline \multirow{2}{*}{$\begin{array}{l}\text { 3. A mandatory reporting } \\
\text { process is necessary for } \\
\text { children to live a safe and } \\
\text { healthy life. }\end{array}$} & Disagree/Neutral & 3 & 8,11 & 5 & 10,20 & \multirow{2}{*}{-} & \multirow{2}{*}{0,740} \\
\hline & Agree & 34 & 91,89 & 44 & 89,80 & & \\
\hline \multirow{2}{*}{$\begin{array}{l}\text { 4. Although my colleagues and } \\
\text { managers at the institution I } \\
\text { work for do not agree with me, } \\
\text { I report situations that I find } \\
\text { suspicious. }\end{array}$} & Disagree/Neutral & 3 & 8,11 & 4 & 8,16 & \multirow{2}{*}{ - } & \multirow{2}{*}{0,993} \\
\hline & Agree & 34 & 91,89 & 45 & 91,84 & & \\
\hline \multirow{2}{*}{$\begin{array}{l}\text { 5. In order to reduce and } \\
\text { prevent child abuse and } \\
\text { neglect in the long run, I think } \\
\text { it is important for teachers to } \\
\text { fulfill their reporting } \\
\text { obligation. }\end{array}$} & Disagree/Neutral & 1 & 2,70 & 2 & 4,08 & \multirow[b]{2}{*}{ - } & \multirow[b]{2}{*}{0,730} \\
\hline & Agree & 36 & 97,30 & 47 & 95,92 & & \\
\hline \multirow{2}{*}{$\begin{array}{l}\text { 6. I find the current system } \\
\text { effective and sufficient in } \\
\text { responding to reports of child } \\
\text { abuse and neglect and meeting } \\
\text { the need. }\end{array}$} & Disagree/Neutral & 30 & 81,08 & 38 & 77,55 & \multirow[b]{2}{*}{0,159} & \multirow[b]{2}{*}{0,690} \\
\hline & Agree & 7 & 18,92 & 11 & 22,45 & & \\
\hline \multirow{2}{*}{$\begin{array}{l}\text { 7. Especially for teachers, I } \\
\text { think it is necessary to have a } \\
\text { regulation that defines the } \\
\text { reporting process of child } \\
\text { abuse and neglect and clearly } \\
\text { states the actions that need to } \\
\text { be taken. }\end{array}$} & Disagree/Neutral & 2 & 5,41 & 11 & 22,45 & \multirow{2}{*}{-} & \multirow{2}{*}{$0,029^{*}$} \\
\hline & Agree & 35 & 94,59 & 38 & 77,55 & & \\
\hline \multirow{2}{*}{$\begin{array}{l}\text { 8. I believe that reporting for } \\
\text { suspicious situations will cause } \\
\text { teachers to experience } \\
\text { difficulties both inside and } \\
\text { outside the school. }\end{array}$} & Disagree/Neutral & 17 & 45,95 & 24 & 48,98 & \multirow[b]{2}{*}{0,078} & \multirow[b]{2}{*}{0,780} \\
\hline & Agree & 20 & 54,05 & 25 & 51,02 & & \\
\hline \multirow{2}{*}{$\begin{array}{l}\text { 9. Even if I report child abuse } \\
\text { and neglect, I think I will not } \\
\text { be able to get enough evidence } \\
\text { or witnesses to prove the truth } \\
\text { of the incident. }\end{array}$} & Disagree/Neutral & 15 & 40,54 & 31 & 63,27 & \multirow[b]{2}{*}{4,376} & \multirow[b]{2}{*}{$0,036^{*}$} \\
\hline & Agree & 22 & 59,46 & 18 & 36,73 & & \\
\hline \multirow{2}{*}{$\begin{array}{l}\text { 10. Reporting child abuse and } \\
\text { neglect helps authorities reach } \\
\text { children and families and } \\
\text { resolve the problem. }\end{array}$} & Disagree/Neutral & 10 & 27,03 & 9 & 18,37 & \multirow{2}{*}{0,918} & \multirow{2}{*}{0,338} \\
\hline & Agree & 27 & 72,97 & 40 & 81,63 & & \\
\hline \multirow{2}{*}{$\begin{array}{l}\text { 11. In the post-reporting } \\
\text { process, I am concerned that } \\
\text { the family or community may } \\
\text { display angry and aggressive } \\
\text { attitudes towards the notifier. }\end{array}$} & Disagree/Neutral & 15 & 40,54 & 23 & 46,94 & \multirow{2}{*}{0,350} & \multirow{2}{*}{0,554} \\
\hline & Agree & 22 & 59,46 & 26 & 53,06 & & \\
\hline \multirow{2}{*}{$\begin{array}{l}\text { 12. After reporting of child } \\
\text { abuse and neglect, I abstain } \\
\text { from being involved in the } \\
\text { process, as I am concerned that }\end{array}$} & Disagree/Neutral & 27 & 72,97 & 37 & 75,51 & \multirow[t]{2}{*}{0,071} & \multirow[t]{2}{*}{0,789} \\
\hline & Agree & 10 & 27,03 & 12 & 24,49 & & \\
\hline
\end{tabular}




\begin{tabular}{|c|c|c|c|c|c|c|c|}
\hline $\begin{array}{l}\text { the child's family and society } \\
\text { will find out who reported the } \\
\text { incident. }\end{array}$ & & & & & & & \\
\hline \multirow{2}{*}{$\begin{array}{l}\text { 13. After the reporting process, } \\
\text { I think that the competent } \\
\text { authorities will intervene } \\
\text { quickly and effectively with } \\
\text { the child and family. }\end{array}$} & Disagree/Neutral & 19 & 51,35 & 22 & 44,90 & \multirow{2}{*}{0,352} & \multirow{2}{*}{0,553} \\
\hline & Agree & 18 & 48,65 & 27 & 55,10 & & \\
\hline \multirow{2}{*}{$\begin{array}{l}\text { 14. I do not think reports about } \\
\text { child abuse and neglect are } \\
\text { taken into account effectively. }\end{array}$} & Disagree/Neutral & 19 & 51,35 & 28 & 57,14 & \multirow[t]{2}{*}{0,285} & \multirow[t]{2}{*}{0,593} \\
\hline & Agree & 18 & 48,65 & 21 & 42,86 & & \\
\hline \multirow{2}{*}{$\begin{array}{l}\text { 15. I believe that my } \\
\text { undergraduate education has } \\
\text { provided me with sufficient } \\
\text { knowledge and skills in } \\
\text { understanding and evaluating } \\
\text { children's behavior and } \\
\text { emotions and communicating } \\
\text { with children. }\end{array}$} & Disagre/Neutral & 6 & 16,22 & 12 & 24,49 & \multirow{2}{*}{0,872} & \multirow{2}{*}{0,350} \\
\hline & Agree & 31 & 83,78 & 37 & 75,51 & & \\
\hline
\end{tabular}

${ }^{*} \mathrm{p}<0,05$-Fisher's Exact Test was used.

When the data in Table 5 are examined, $97.30 \%$ of the teachers who received education on child abuse and neglect, and $93.88 \%$ of the teachers who did not receive education responded as I agree with the statement "1. If I am in doubt about child abuse or neglect, I will report it." Besides, no statistically significant difference was found between the answers they gave according to their education on child abuse and neglect $(p>0,05)$. $75.68 \%$ of those who received education on child abuse and neglect, and $61.22 \%$ of those who did not receive education answered as I agree with the "2. I believe that I have full professional competence in understanding and interpreting the symptoms of child abuse or neglect" statement and there was no significant difference between the responses of teachers according to their education on child abuse and neglect $(p>0,05) .91 .89 \%$ of teachers who received education on child abuse and neglect and $89.80 \%$ of teachers who did not receive education responded as I agree with the "3. A mandatory reporting process is necessary for children to live a safe and healthy life." statement. Moreover, it was determined that the difference between the responses did not differ significantly according to education on child abuse and neglect $(p>0,05)$.

According to the participants' education on child abuse and neglect, $91.89 \%$ of the educated teachers and $91.84 \%$ of the non-educated teachers responded as I agree with the statement "4. Although my colleagues and managers at the institution I work for do not agree with me, I report situations that I find suspicious" and it was found that the difference between the answers was not statistically significant ( $p>0,05)$. 97.30\% of those who received education on child abuse and neglect, and $95.92 \%$ of those who did not receive education agreed with the "5. In order to reduce and prevent child abuse and neglect in the long run, I think it is important for teachers to fulfill their reporting obligation" statement. It was observed that the difference between the responses according to their educational level 
on child abuse and neglect was not statistically significant ( $p>0,05) .18 .92 \%$ of the teachers who received education and $22.45 \%$ of the teachers who did not receive education agreed with the "6. I find the current system effective and sufficient in responding to reports of child abuse and neglect and meeting the need." statement and no statistically significant difference was found between the answers they gave according to their education on child abuse and neglect $(\mathrm{p}>0,05)$.

$94.59 \%$ of the teachers who received education on child abuse and neglect and $77.55 \%$ of the teachers who did not receive education agreed with the statement " 7 . Especially for teachers, I think it is necessary to have a regulation that defines the reporting process of child abuse and neglect and clearly states the actions that need to be taken." It has been determined that the difference between the responses given by the teachers shows a statistically significant difference according to the education on child abuse and neglect $(p<0,05) .54,05 \%$ of the teachers who received education on child abuse and neglect and $51,02 \%$ of the teachers who did not receive education agreed with the statement " 8 . I believe that reporting for suspicious situations will cause teachers to experience difficulties both inside and outside the school." and it was also observed that there was no statistically significant difference between the teachers' responses according to their education on child abuse and neglect $(\mathrm{p}>0,05)$. Among the participants, those who answered I agree with the "9. Even if I report child abuse and neglect, I think I will not be able to get enough evidence or witnesses to prove the truth of the incident." statement were $59.46 \%$ of those who received education on child abuse and neglect, and $36.73 \%$ of those who did not. For this statement, statistically significant difference was found between the answers given by the teachers according to their education on child abuse and neglect $(p<0,05)$.

$72.97 \%$ of the teachers who received education on child abuse and neglect and $81.63 \%$ of those who did not receive education responded as I agree with the statement "10. Reporting child abuse and neglect helps authorities reach children and families and resolve the problem." and it was indicated that the difference between the responses did not show a significant difference according to the education on child abuse and neglect $(\mathrm{p}>0,05)$. $59.46 \%$ of those who received education on child abuse and neglect and $53.06 \%$ of those who did not received education responded to the "11. In the post-reporting process, I am concerned that the family or community may display angry and aggressive attitudes towards the notifier." statement as I agree. Besides, it was determined that the difference between teachers' responses according to their education on child abuse and neglect was not statistically significant ( $p>0,05) .27 .03 \%$ of the teachers who received education on child abuse and neglect and $24.49 \%$ of the teachers who did not receive education on this subject answered I agree with the statement "12. After reporting of child abuse and neglect, I abstain from being involved in the process, as I am concerned that the child's family and society will find out who reported the incident." and it was indicated that the difference between the responses did not differ greatly according to the educational status on child abuse and neglect $(p>0,05)$.

Of the teachers who agreed with the "13. After the reporting process, I think that the competent authorities will intervene quickly and effectively with the child and family." statement, 
$48.65 \%$ received education on child abuse and neglect while $55.10 \%$ did not. It was found that the difference between teachers ' responses to this statement according to their educational background on child abuse and neglect was not statistically significant $(p>0,05) .48,65 \%$ of the teachers who received education on child abuse and neglect and $42,86 \%$ of the teachers who did not receive education on this subject responded as I agree with the statement "14. I do not think reports about child abuse and neglect are taken into account effectively." and no significant difference was found between teachers' responses according to their education on child abuse and neglect $(p>0,05)$. The teachers who responded as I agree with the "15. I believe that my undergraduate education has provided me with sufficient knowledge and skills in understanding and evaluating children's behavior and emotions and communicating with children." statement are $83.78 \%$ of those who received education on child abuse and neglect, and $75.51 \%$ of those who did not receive education. No statistically significant difference was found between the responses of teachers to this statement regarding their education on child abuse and neglect $(p>0,05)$.

Table 6: Comparison of Teachers ' Responses to the Teacher Attitudes Survey

Towards the Reporting of Child Abuse and Neglect According to the State of Abuse $(n=86)$

\begin{tabular}{|c|c|c|c|c|c|c|c|}
\hline & & \multicolumn{2}{|c|}{ Abused } & \multicolumn{2}{|c|}{ Non-Abused } & \multirow{2}{*}{$\chi^{2}$} & \multirow{2}{*}{$\mathrm{p}$} \\
\hline & & $\mathrm{n}$ & $\%$ & $\mathbf{n}$ & $\%$ & & \\
\hline \multirow{2}{*}{$\begin{array}{l}\text { 1. If I am in doubt about child } \\
\text { abuse or neglect, I will report } \\
\text { it. }\end{array}$} & Disagree/Neutral & 0 & 0,00 & 4 & 5,48 & \multirow{2}{*}{-} & \multirow{2}{*}{0,387} \\
\hline & Agree & 13 & 100,00 & 69 & 94,52 & & \\
\hline \multirow{2}{*}{$\begin{array}{l}\text { 2. I believe that I have full } \\
\text { professional competence in } \\
\text { understanding and } \\
\text { interpreting the symptoms of } \\
\text { child abuse or neglect. }\end{array}$} & Disagree/Neutral & 3 & 23,08 & 25 & 34,25 & \multirow{2}{*}{-} & \multirow{2}{*}{0,428} \\
\hline & Agree & 10 & 76,92 & 48 & 65,75 & & \\
\hline \multirow{2}{*}{$\begin{array}{l}\text { 3. A mandatory reporting } \\
\text { process is necessary for } \\
\text { children to live a safe and } \\
\text { healthy life. }\end{array}$} & Disagree/Neutral & 0 & 0,00 & 8 & 10,96 & \multirow{2}{*}{-} & \multirow{2}{*}{0,210} \\
\hline & Agree & 13 & 100,00 & 65 & 89,04 & & \\
\hline \multirow{2}{*}{$\begin{array}{l}\text { 4. Although my colleagues and } \\
\text { managers at the institution I } \\
\text { work for do not agree with me, } \\
\text { I report situations that I find } \\
\text { suspicious. }\end{array}$} & Disagree/Neutral & 0 & 0,00 & 7 & 9,59 & \multirow{2}{*}{-} & \multirow{2}{*}{0,244} \\
\hline & Agree & 13 & 100,00 & 66 & 90,41 & & \\
\hline \multirow{2}{*}{$\begin{array}{l}\text { 5. In order to reduce and } \\
\text { prevent child abuse and } \\
\text { neglect in the long run, I think } \\
\text { it is important for teachers to } \\
\text { fulfill their reporting } \\
\text { obligation. }\end{array}$} & Disagree/Neutral & 0 & 0,00 & 3 & 4,11 & & \multirow{2}{*}{0,457} \\
\hline & Agree & 13 & 100,00 & 70 & 95,89 & & \\
\hline \multirow{2}{*}{$\begin{array}{l}\text { 6. I find the current system } \\
\text { effective and sufficient in } \\
\text { responding to reports of child } \\
\text { abuse and neglect and meeting } \\
\text { the need. }\end{array}$} & Disagree/Neutral & 12 & 92,31 & 56 & 76,71 & \multirow[b]{2}{*}{-} & \multirow{2}{*}{0,203} \\
\hline & Agree & 1 & 7,69 & 17 & 23,29 & & \\
\hline
\end{tabular}


Fatima Şenda Değirmenci, Cahit Nuri, Cemaliye Direktör

EXAMINATION OF ATTITUDES OF SPECIAL EDUCATION TEACHERS TOWARDS

CHILD NEGLECT AND ABUSE REPORTING IN TERMS OF DIFFERENT VARIABLES

\begin{tabular}{|c|c|c|c|c|c|c|c|}
\hline \multirow{2}{*}{$\begin{array}{l}\text { 7. Especially for teachers, I } \\
\text { think it is necessary to have a } \\
\text { regulation that defines the } \\
\text { reporting process of child } \\
\text { abuse and neglect and clearly } \\
\text { states the actions that need to } \\
\text { be taken. }\end{array}$} & Disagree/Neutral & 0 & 0,00 & 13 & 17,81 & \multirow[b]{2}{*}{-} & \multirow[b]{2}{*}{0,099} \\
\hline & Agree & 13 & 100,00 & 60 & 82,19 & & \\
\hline \multirow{2}{*}{$\begin{array}{l}\text { 8. I believe that reporting for } \\
\text { suspicious situations will cause } \\
\text { teachers to experience } \\
\text { difficulties both inside and } \\
\text { outside the school. }\end{array}$} & Disagree/Neutral & 4 & 30,77 & 37 & 50,68 & \multirow{2}{*}{-} & \multirow{2}{*}{0,185} \\
\hline & Agree & 9 & 69,23 & 36 & 49,32 & & \\
\hline \multirow{2}{*}{$\begin{array}{l}\text { 9. Even if I report child abuse } \\
\text { and neglect, I think I will not } \\
\text { be able to get enough evidence } \\
\text { or witnesses to prove the truth } \\
\text { of the incident. }\end{array}$} & Disagree/Neutral & 2 & 15,38 & 44 & 60,27 & & \multirow{2}{*}{$0,003^{*}$} \\
\hline & Agree & 11 & 84,62 & 29 & 39,73 & & \\
\hline \multirow{2}{*}{$\begin{array}{l}\text { 10. Reporting child abuse and } \\
\text { neglect helps authorities reach } \\
\text { children and families and } \\
\text { resolve the problem. }\end{array}$} & Disagree/Neutral & 5 & 38,46 & 14 & 19,18 & & \multirow{2}{*}{0,123} \\
\hline & Agree & 8 & 61,54 & 59 & 80,82 & & \\
\hline \multirow{2}{*}{$\begin{array}{l}\text { 11. In the post-reporting } \\
\text { process, I am concerned that } \\
\text { the family or community may } \\
\text { display angry and aggressive } \\
\text { attitudes towards the notifier. }\end{array}$} & Disagree/Neutral & 4 & 30,77 & 34 & 46,58 & & \multirow{2}{*}{0,290} \\
\hline & Agree & 9 & 69,23 & 39 & 53,42 & & \\
\hline \multirow{2}{*}{$\begin{array}{l}\text { 12. After reporting of child } \\
\text { abuse and neglect, I abstain } \\
\text { from being involved in the } \\
\text { process, as I am concerned that } \\
\text { the child's family and society } \\
\text { will find out who reported the } \\
\text { incident. }\end{array}$} & Disagree/Neutral & 11 & 84,62 & 53 & 72,60 & & \multirow{2}{*}{0,360} \\
\hline & Agree & 2 & 15,38 & 20 & 27,40 & & \\
\hline \multirow{2}{*}{$\begin{array}{l}\text { 13. After the reporting process, } \\
\text { I think that the competent } \\
\text { authorities will intervene } \\
\text { quickly and effectively with } \\
\text { the child and family. }\end{array}$} & Disagree/Neutral & 8 & 61,54 & 33 & 45,21 & & \multirow[b]{2}{*}{0,277} \\
\hline & Agree & 5 & 38,46 & 40 & 54,79 & & \\
\hline \multirow{2}{*}{$\begin{array}{l}\text { 14. I do not think reports about } \\
\text { child abuse and neglect are } \\
\text { taken into account effectively. }\end{array}$} & Disagree/Neutral & 6 & 46,15 & 41 & 56,16 & \multirow{2}{*}{0,446} & \multirow{2}{*}{0,504} \\
\hline & Agree & 7 & 53,85 & 32 & 43,84 & & \\
\hline \multirow{2}{*}{$\begin{array}{l}\text { 15. I believe that my } \\
\text { undergraduate education has } \\
\text { provided me with sufficient } \\
\text { knowledge and skills in } \\
\text { understanding and evaluating } \\
\text { children's behavior and } \\
\text { emotions and communicating } \\
\text { with children. }\end{array}$} & Disagree/Neutral & 7 & 53,85 & 11 & 15,07 & \multirow[b]{2}{*}{10,026} & \multirow[b]{2}{*}{$0,002^{*}$} \\
\hline & Agree & 6 & 46,15 & 62 & 84,93 & & \\
\hline
\end{tabular}

${ }^{*} \mathrm{p}<0.05$-Fisher's Exact Test was used. 
When Table 6 is examined, all of the teachers in the study who were abused and $90.41 \%$ of those who were not abused stated that they agreed with the "4. Although my colleagues and managers at the institution I work for do not agree with me, I report situations that I find suspicious." statement. It was determined that there was no statistically significant difference between the responses according to the state of abuse(p>0,05). Those who answered I agree with the "5. In order to reduce and prevent child abuse and neglect in the long run, I think it is important for teachers to fulfill their reporting obligation" statement are all of the teachers who were abused and $95.89 \%$ of those who were not abused. It was noted that there was no statistically great difference between the teachers' responses to this statement according to their state of abuse $(p>0,05)$.

The rate of participants who stated that they agree with the "6. I find the current system effective and sufficient in responding to reports of child abuse and neglect and meeting the need." statement was $7.69 \%$ for the teachers who were abused, and $23.29 \%$ for the teachers who were not abused. It was observed that the difference between their responses did not show a statistically significant difference regarding the situation of being abused $(\mathrm{p}>0,05)$. All of the participants who were abused and $82.19 \%$ of the participants who were not abused answered that they agree with the "7. Especially for teachers, I think it is necessary to have a regulation that defines the reporting process of child abuse and neglect and clearly states the actions that need to be taken." statement and it was determined that there was no significant difference between the teachers' responses according to their situation of being abused ( $p>0,05) .69 .23 \%$ of teachers who were abused and $49.32 \%$ of those who were not abused responded as "I agree with the statement 8. I believe that reporting for suspicious situations will cause teachers to experience difficulties both inside and outside the school." and it was found that there was no statistically significant difference between the answers given by the teachers according to the state of being abused $(p>0,05) .84 .62 \%$ of the teachers who were abused and $39.73 \%$ of the teachers who were not abused indicated that they agreed with the statement "9. Even if I report child abuse and neglect, I think I will not be able to get enough evidence or witnesses to prove the truth of the incident." It was found that there is a statistically significant difference between the teachers' responses to this statement according to their state of being abused $(\mathrm{p}<0,05) .61 .54 \%$ of the participants who were abused and $80.82 \%$ of the participants who were not abused, stated that they agree with the "10. Reporting child abuse and neglect helps authorities reach children and families and resolve the problem." statement and no significant difference was found between the responses according to the state of being abused $(\mathrm{p}>0,05)$. The rate of participants who indicated that they agree with the "11. In the post-reporting process, I am concerned that the family or community may display angry and aggressive attitudes towards the notifier." statement was $69,23 \%$ for the teachers who were abused, and 53,42\% for the teachers who were not abused. It was found that the difference between the responses did not show a statistically significant difference regarding the state of being abused $(p>0,05)$. While $15.38 \%$ of the abused participants answered I agree with the statement "12. After reporting of child abuse and neglect, I abstain from being involved in the process, as I am concerned that the child's family and society will find out who reported the incident." this rate was $27.40 \%$ for the 
participants who were not abused. There was no statistically significant difference among the responses of the teachers to this statement according to their state of being abused $(p>0,05) .38 .46 \%$ of the participants who were abused and $54.79 \%$ of those who were not abused responded as I agree with the "13. After the reporting process, I think that the competent authorities will intervene quickly and effectively with the child and family" statement and there was no statistically significant difference between the responses according to the state of being abused ( $>00,05) .53 .85 \%$ of the abused teachers and $43.84 \%$ of those who were not abused stated that they agreed with the "14. I do not think reports about child abuse and neglect are taken into account effectively" statement and it was determined that the difference between the answers they gave did not show a significant difference according to the state of being abused ( $p>0,05)$.

$46.15 \%$ of teachers who were abused and $84.93 \%$ of those who were not abused responded as "I agree with the statement 15. I believe that my undergraduate education has provided me with sufficient knowledge and skills in understanding and evaluating children's behavior and emotions and communicating with children." For this statement, it was found that the difference between teachers ' responses according to the state of being abused was statistically significant $(\mathrm{p}<0,05)$.

\section{Conclusion and Discussion}

In this section, a discussion is included in the light of the findings of the research. In spite of the extraordinary technological and scientific developments experienced today, despite the legal regulations, education and health facilities and scientific research results, it is a great contradiction that child abuse and neglect, which constitutes the most basic threat and risk to children, is so common (Cakar \& Okuyan, 2017). It is aimed to achieve long-term prevention and reduction goals by preparing educational programs to protect the child from all types of maltreatment and by informing both children and individuals in society. However, it is clearly seen that $56.98 \%$ of the participating teachers in the study did not receive education on child abuse and neglect. Teachers' lack of education on child abuse and neglect can cause prevention and intervention services to be disrupted, faulty practices to occur, and child victimization to be prolonged (Yetis \& Ziyalar, 2018).

A statistically significant difference was observed between the opinions of the participating teachers regarding the "I find the current system effective and sufficient in responding to reports of child abuse and neglect and meeting the need." statement according to their gender. In this regard, it can be said that women teachers develop a greater attitude, and that they consider the activities of the relevant institutions on child abuse more inadequate than male teachers. It can be argued that the attitude developed by female teachers that institutions do not take adequate measures on child abuse is related to the fact that the experience they have gained due to childcare strengthens their sensitivity on this issue. On the other hand, the fact that the observed cases of abuse against children come substantially from men suggests that female teachers develop a greater attitude to 
this issue. In her study of teachers' views on child abuse, Kenny (2001) concluded that there was no significant difference in the case reporting and reporting of participants. Farrell and Walsh (2010) stated that for teachers to have the necessary knowledge and self-confidence to cope with legal, professional, and social processes in this regard, education on child neglect and abuse should be organized in a systematic and planned manner.

As the duration of teachers' professional experience differed, differences were also observed between their views on child abuse. A statistically significant difference was observed between the opinions of the teachers in the "In order to reduce and prevent child abuse and neglect in the long run, I think it is important for teachers to fulfill their reporting obligation." , "I find the current system effective and sufficient in responding to reports of child abuse and neglect and meeting the need." and "Reporting child abuse and neglect helps authorities reach children and families and resolve the problem." items according to the duration of their professional experience. On this basis, it can be said that teachers who have professional experience of 16 years or more developed a greater attitude about the responsibility of reporting child abuse to the relevant institutions, the effectiveness and efficiency of the activities of the institutions regarding child abuse, and the help of the relevant institutions for abuse compared to the teachers who have 15 years or less experience. The more positive attitude of teachers who have professional experience of 16 years or more towards institutions that will help preventing abuse, can be explained by the fact that employees express their dissatisfaction less and less as time goes on. From another point of view, it can be said that since more senior teachers are more experienced in how to cooperate with relevant institutions on child abuse, they can see the activities of the institutions on this issue fit and proper. In the study conducted by Catık and Cam (2006), it was determined that there is a relationship between professional experience, child abuse and informing level. According to the results of the study, it was concluded that as the professional seniority of the participants increased, their knowledge level of this field increased. Trying to reach children without being exposed to sexual abuse is important in terms of preventing their exposure to abuse. From the moment children start school, teachers know about children as much as their parents, as they spend the vast majority of their time outside the home in the school environment. For this reason, teachers are the ones who can best notice the negativity experienced by children. Teachers play a major role in identifying and preventing sexual abuse (Yasar \& Senol, 2015; Fayez, Takash ve Alzboon, 2014; Walsh, Bridgstock, Farrella, Rassafianib, Schweitzer, 2008).

Some differences were also observed between the teachers' views on child abuse according to whether they were educated on child abuse or not. A statistically significant difference was observed between the opinions of the teachers in the "Especially for teachers, I think it is necessary to have a regulation that defines the reporting process of child abuse and neglect and clearly states the actions that need to be taken." and "Even if I report child abuse and neglect, I think I will not be able to get enough evidence or witnesses to prove the truth of the incident." items according to their level of education on the subject. Kenny (2004), Webster, O'Toole, O'Toole and Lucal (2005) and Goebbels, Nicholson, Walsh, and De 
Vries (2008) stated in their research that teachers who received education on child abuse reported more child abuse than teachers who did not receive education. It can be said that teachers who have received training on the subject have developed more attitudes towards improving the legal legislation on child abuse and measures to be taken against it, than teachers who did not receive education on this subject, and that the education they received increased their awareness of child abuse. In addition, the teachers who did not receive education on this subject developed more negative views on the difficulty of reaching sufficient information, documents and arguments to prove abuse. It was observed that teachers who were trained on abuse had more information on how to obtain more evidence on proving child abuse. Farrell and Walsh (2010) emphasized that in order for teachers to have the necessary knowledge and self-confidence to cope with legal, professional and social processes in this regard, education on child neglect and abuse should be organized in a systematic and planned manner.

Among the participating teachers, it was observed that those who had previously been abused and those who had not experienced abuse expressed different views on the two items of the survey. In the "Even if I report child abuse and neglect, I think I will not be able to get enough evidence or witnesses to prove the truth of the incident." item, teachers who were abused in their childhood expressed more opinions. To this respect, it can be said that teachers who are abused feel more helpless. Teachers who had not been abused in their childhood expressed more opinions on "I believe that my undergraduate education has provided me with sufficient knowledge and skills in understanding and evaluating children's behavior and emotions and communicating with children." Based on this, it can be added that teachers who have not been abused in their childhood are more confident in understanding children's behaviors and emotions. Teachers who were abused in their childhood, on the other hand, thought that the trauma caused by the abuse and that this was not adequately treated, they considered the education received partially sufficient in understanding and evaluating children. When the related body of literature is examined, studies reaching similar results to the findings of this study were found. Similar results were obtained in the study conducted by Dereobalı, Cirak Karadag and Sonmez (2013). It was noted that a small proportion of the educators participating in the study received education on child abuse. In the sample study, the participants were of the opinion that teachers should carry out more informative activities about abuse and violence against children, and in a sense, they should be role models. Many teachers expressed that they consider contacting the Counseling and Research Center when they encounter children who have experienced violence or abuse. Similar results were reached in the study conducted by Yetis and Ziyalar (2017). It was observed that a significant portion of the educators did not receive any education on child abuse, yet they had knowledge about the relevant legislation, they found the measures taken by the institutions regarding child abuse partially sufficient, however they thought that more should be taken in this regard.

Similar aspects stand out in many studies on reporting abuse against children. Among them, what attracts the most attention and supports the results achieved in this study is that teachers are afraid of social reactions. In addition, it is also common for 
teachers to have difficulties in producing adequate alternatives for what to do if they receive information about the case, and they have deficiencies in guiding families, as they generally do not receive education on this subject. In some studies, it can be claimed that not only the teacher but the other stakeholders of the subject, the school, the family, and the guidance services need an action plan in which they can act together (Tas, 2017; Bilge et al., 2013; Choo et al., 2013; Sarıbas, 2013; Sagır, 2013; Kurklu, 2011; Turk, 2010; Keser \& Odabaş, 2010; Aktepe, 2009; Bahar, Savaş \& Bahar, 2009; Ozturk, 2007; T1rascı \& Gonen, 2007; Taner \& Gokler, 2004; Polat, 2000).

\section{Recommendations}

To conclude, it is important for teachers to have knowledge of the legal legislation on abuse of children, what civil and public institutions they can reach on this issue and which joint activities can be carried out with them, what reactions they can give in times of crisis or critical situations, and how they can direct people. It can be shown as a requirement that they receive in-service training on these issues. The fact that school administrators and guidance research units have sufficient knowledge to take precautions on the subject will also contribute to the prevention of abuse against children. Information, constructive support and the preparation of guiding manuals for families who are other stakeholders in this issue also play an important role in this matter.

\section{Conflict of Interest Statement}

The authors declare that they have no competing interests.

\section{About the Author}

Fatima Şenda Değirmenci has completed her non-thesis graduate from in Teaching the Mentally Disabled at the Cyprus International University, North Cyprus. Her research interests include education of children with special needs, child neglect and abuse, and sexuality and sexual education of children with special needs. https://orcid.org/0000$\underline{0002-1556-3020}$

Assist. Prof. Dr. Cahit Nuri is a faculty member and head of the Department of Special Education, Cyprus International University. His research on Attention Deficit Hyperactivity Disorder, Autism Spectrum Disorder, Family Education and the sexuality and sexual education of children with special needs. https://orcid.org/0000-0003-0805$\underline{1972}$

Assist. Prof. Dr. Cemaliye Direktör is working as a lecturer at the European University of Lefke, Faculty of Arts and Sciences, Department of Psychology. Her research interests include psychological factors in Child Abuse, Addictions and Special Needs Child Education. https://orcid.org/0000-0002-6055-2224 


\section{References}

Akgul E, 2015. A study about reporting status of child sexual abuse by the staff working in preschool education centers (Master Thesis). Hacettepe University, Institute of Educational Sciences, Ankara.

Bahar G, Savas H, Bahar A, 2009. Child abuse and neglect: A review. Fırat Saglık Hizmetleri Dergisi, 4(12), 51-65.

Bilge YD, Taşar MA, Kılıncoglu B, Ozmen S, Tıras U, 2013. Socioeconomic status lower levels of parental knowledge aboutchild abuse, neglect, experiences and discipline methods used. Anadolu Psikiyatri Dergisi, 14(1), 27-35.

Bostancı N, Albayrak B, Bakoglu I, Coban S, 2006. The impact to depressive symptom levels of childhood abuse in university students. In New/Yeni Symposium Journal (Vol. 44, No. 4, pp. 189-195).

Choo WY, Walsh K, Chinna K, Tey NP, 2013. Teacher Reporting Attitudes Scale (TRAS): confirmatory and exploratory factor analyses with a Malaysian sample. J Interpers Violence, 28 (2): 231-53.

Cakar FS, Okuyan HY, 2017. Trainee Teachers' Opinions about Child Abuse and Neglect. Mehmet Akif Ersoy University Journal of Education Faculty, (44), 250-275.

Dereobalı N, Cirak Karadag S, Sonmez S, 2013. Preschool Educators' Roles Views and Experiences About Child Abuse Neglect and Violence Towards Children. Ege Journal of Education, (14) 1: 50-66.

Dilsiz H, Magden D, 2015. Ogretmenlerin cocuk istismar ve ihmali konusunda bilgi ve risk tanıma düzeylerinin tespit edilmesi. Hacettepe University Faculty of Health Sciences Journal, 1, (2): 678-694.

Farrell A, Walsh K, 2010. Working together for Toby: Early childhood student teachers engaging in collaborative problem-based learning around child abuse and neglect. Australasian Journal of Early Childhood, 35(4), 53-62.

Fayez M, Takash MH, Al-Zboon KE, 2014. Combating violence against children: Jordanian pre-service early childhood teachers' perceptions towards child abuse and neglect. Early Child Development and Care, 184(9-10), 1485-1498.

Goebbels AFG, Nicholson JM, Walsh K, De Vries H, 2008. Teachers' reporting of suspected child abuse and neglect: Behavior and determinants. Health Education Research, 23(6), 941-951.

Kara B, Bicer U, Gökalp AS, 2004. Cocuk Istismarı. Çocuk Sağhl̆ğı ve Hastalıkları Dergisi, 47, 140-151.

Karasar N, 2012. Scientific research method. Ankara: Nobel Yayıncllik.

Kenny MC, 2001. Child Abuse Reporting: Teachers' Perceived Deterrrents. Child Abuse $\mathcal{E}$ Neglect, 25 (Suppl.): 81-92.

Kenny MC, 2004. Teachers' attitudes toward and knowledge of child maltreatment. Child Abuse \& Neglect, 28(12), 1311-1319.

Keser N., Odabas E., \& Elibuyuk, S. (2010). The evaluation of parents' knowledge about child abuse. Turkish Journal of Pediatric Disease, 4(3), 150-157. 
Kocaer U, 2006. Levels of awareness in doctors and nurses regarding child abuse and neglect (Master Thesis). Marmara University, Institute of Health Sciences, Istanbul.

Kurklu A, 2011. Levels of teachers? awareness about child exploitation and negligence (Master Thesis). Afyon Kocatepe University Institute of Health Sciences, Afyon.

Ozturk S, 2007. Emotional abuse of children (Master Thesis). Frrat University, Institute of Social Sciences, Elazı ̆.

Polat O, 2000. Child abuse. Adli Tip Dergisi Yayınevi: İstanbul.

Sagir M, 2013. Pre-school teachers' and primary school teachers' views and awareness levels about child abuse and neglect (Master Thesis). Erciyes University, Institute of Educational Sciences, Department of Educational Sciences, Kayseri.

Sarıbas AK, 2013. Determination of pre-school teachers' awareness for child abuse. (Master Thesis), Çanakkale Onsekiz Mart University, Institute of Educational Sciences, Çanakkale.

Siyez DM, 2003. Self-esteem, depression and, anxiety levels in emotionally abused and nonabused adolescents (Master Thesis). Dokuz Eylül University, Institute of Educational Sciences, İzmir.

Taner Y, Gökler B, 2004. Cocuk istismarı ve ihmali: Psikiyatrik yönleri. Acta Medica, 35(2), 82-86.

Tas A, 2017. Investigation of the knowlegde levels of the Hacettepe University about neglect and abuse against children (Master Thesis). Hacettepe University, Institute of Social Sciences, Ankara.

Tirasc1 Y, Goren S, 2007. Child Abuse and Neglect. Dicle Medical Journal, 34(1), 70-74.

Turk S, 2010. Research of teacher candidates and teachers works on primary school in terms of child abuse potential (Master Thesis). Zonguldak Karaelmas University, Institute of Social Sciences, Zonguldak.

Walsh K, Bridgstock R, Farrella A, Rassafianib M, Schweitzer R, 2008. Case, teacher and school characteristics influencing teachers' detection and reporting of child physical abuse and neglect: Results from an Australian survey. Child Abuse $\mathcal{E}$ Neglect, 32(10), 983-993.

Webster SW, O'Toole R, O'Toole AW, Lucal B, 2005. Over reporting and under reporting of child abuse: Teachers' use of professional discretion. Child Abuse $\mathcal{E}$ Neglect, 29(11), 1281-1296.

Yarg1c I, Ersoy E, Batmaz-Oflaz S, 2012. The relation of childhood trauma with suicide attempt and self-mutilation. Anatolian Journal of Psychiatry, 13, 277-284.

Yasar M, Senol B, 2015. Öğretmen adaylarının çocuğa yönelik cinsel istismar tutumlarının incelenmesi. Hacettepe University Faculty of Health Sciences Journal.

Yetis O, Ziyalar N, 2018. Cocuk istismarı ve ihmalinin bildirimine yonelik ogretmen tutumlar1. Turkiye Klinikleri J Foren Sci Leg Med,15(1):10-23. 
Creative Commons licensing terms

Authors will retain the copyright of their published articles agreeing that a Creative Commons Attribution 4.0 International License (CC BY 4.0) terms will be applied to their work. Under the terms of this license, no permission is required from the author(s) or publisher for members of the community to copy, distribute, transmit or adapt the article content, providing a proper, prominent and unambiguous attribution to the authors in a manner that makes clear that the materials are being reused under permission of a Creative Commons License. Views, opinions and conclusions expressed in this research article are views, opinions and conclusions of the author(s). Open Access Publishing Group and European Journal of Special Education Research shall not be responsible or answerable for any loss, damage or liability caused in relation to/arising out of conflict of interests, copyright violations and inappropriate or inaccurate use of any kind content related or integrated on the research work. All the published works are meeting the Open Access Publishing requirements and can be freely accessed, shared, modified, distributed and used in educational, commercial and non-commercial purposes under a Creative Commons Attribution 4.0 International License (CC BY 4.0). 